\title{
Resource partitioning in a snake assemblage from east-central Argentina
}

\author{
DIEGO O. DI PIETRO, JORGE D. WILLIAMS, MARIO R. CABRERA, LEANDRO \\ ALCALDE, RODRIGO CAJADE \& FEDERICO P. KACOLIRIS
}

\begin{abstract}
Two dimensions of the ecological niche (diet and habitat) of a snake assemblage from an endemic rich area in east-central Argentina, the Sierras de Ventania mountain chain, were analyzed. Field data collection was performed in 15-week study periods between 2010 and 2014. Snakes were hand-captured using transect surveys. Field observations on diet were analyzed together with stomach content data from museum specimens. Our results supported the partitioning of the snake assemblage by both habitat use and diet into at least three functional groups: species restricted to microhabitats under rocks and with a diet composed exclusively of ants (Epictia australis); species found mostly in stream microhabitats and feeding mainly upon anurans (Erythrolamprus poecilogyrus and Lygophis elegantissimus); and species found mostly in grassland microhabitats, with specialized diets of terrestrial prey items (Philodryas patagoniensis and Bothrops alternatus). Consistent with previous work, diet was more important than habitat in explaining ecological niche partitioning of this snake assemblage. Our results showed that high overlap values of microhabitat use were compensated by low overlap values of the trophic niche dimension, thus matching the traditional complementary niches hypothesis.
\end{abstract}

Key words: diet, foraging strategies, microhabitat use, niche overlap, snake assemblages.

\section{INTRODUCTION}

Species interactions, such as resource competition and predation, are among the main factors responsible for the structure of communities (i.e., resource partitioning: Schoener 1974). Frequently, the large number of interacting species in a given herpetological community complicates the study of their ecology (Heyer 1988).

The use of community resources is closely linked with the concept of ecological niche (Hutchinson 1957), which includes three main dimensions: food, habitat and time (Pianka 1973, 1975, 1982, Schoener 1974, Toft 1980, 1981, 1985, Jaksic et al. 1981). A distinction must be made between these possible explanations for the structure of a given community (populations sharing geography) or assemblage (populations sharing geography and phylogeny; definitions from Fauth et al. 1996). The current structure of an assemblage may be explained by historical and evolutionary changes that affected species interactions over time or, alternatively, by current interactions Thorpe et al. 1994, Vitt \& Zani 1996) not influenced by phylogeny (Cadle \& Greene 1993). According to Vitt \& Pianka (2005), resource partitioning may be affected by the current competitive abilities of species, which also retain ancestral differences. Thus, historical effects would be maximal and interactions less influential among phylogenetically-distant species, whereas historical effects would 
be minimal and interactions higher among phylogenetically-related species (Vitt \& Pianka 2005, Bellini et al. 2015).

Compared with other squamates, data on the structure of snake assemblages are scarce, probably because they are less abundant and more cryptic than lizards, and often have empty stomachs (Goodyear \& Pianka 2008, Dorcas \& Willson 2009). However, the three dimensions of the ecological niche have been documented in certain snake assemblages (e.g., Henderson 1974, White \& Kolb 1974, Yanosky 1989, Martins \& Oliveira 1998, Luiselli 2006, Goodyear \& Pianka 2008, Bellini et al. 2015). A review of resource partitioning in herpetological communities revealed that the diet was the main niche dimension of snakes, contrasting with the central role of habitat in structuring assemblages of most other amphibians and reptiles (Toft 1985). In another review of snake assemblages, diet explained resource partitioning in $56.80 \%$ of cases (Luiselli 2006).

The optimal foraging theory predicts that predator decisions maximize the net rate of food ingestion, while positive or negative balances depend on the net energy value provided by a prey item and the time spent catching it. Predators thus discriminate among prey to optimize their foraging strategy (Perry \& Pianka 1997). Dominant foraging modes of squamates are better explained by phylogenetic constraints than by current ecological adaptations (Cooper 1995, Schwenk 1995). Generalist and specialist predators represent two ends of a continuum of dietary specialization (Huey \& Pianka 1981, Beaupre \& Montgomery 2007). In addition, passively foraging snakes usually depend on vision and/or thermoreception (loreal pits) to detect moving prey, whereas active foragers mostly depend on chemoreception (tongueflicking/vomeronasal organ) to search for and capture hidden prey (Cooper 1995, Schwenk 1995).

Based on our hypotheses that diet would be a key factor to understand the ecological niche partitioning of the snake assemblage and, alternatively, that habitat/microhabitat use would explain ecological niche partitioning better than diet, we analyzed the trophic and spatial dimensions of the ecological niches of five species from a snake assemblage in the Sierras de Ventania low mountain chain, a highly endemic area in east-central Argentina.

\section{MATERIALS AND METHODS}

\section{Study Area}

The Sierras de Ventania is an isolated orographic system of sub-parallel chains of low mountains located in the southwest of Buenos Aires province, Argentina, between $37.5166^{\circ} \mathrm{S}, 62.8333^{\circ} \mathrm{W}$ and $38.3833^{\circ} \mathrm{S}, 61.2166^{\circ} \mathrm{W}$ (Sellés Martínez 2001). The system covers an area of $7100 \mathrm{~km}^{2}$ from NW to SE (Vargas Gil \& Scoppa 1973). The four main mountain ranges are Sierra de Cura Malal, Sierra de la Ventana, Sierra de las Tunas and Sierra de Pillahuincó, with maximum altitudes of 1015, 1243, 650 and 550 masl, respectively. The area is biologically rich and home to several endemic species, thus explaining why it was defined as an orographic island (Cranwell 1942, Kristensen \& Frangi 1995, Crisci et al. 2001).

The climate of the region is temperate $\left(14^{\circ} \mathrm{C}\right.$ mean annual temperature) and humidsubhumid (800 mm mean annual precipitation; Burgos 1968). Altitudinal temperature gradients decrease by $6.90^{\circ} \mathrm{C} / 1000 \mathrm{~m}$ (Kristensen \& Frangi 1995) and precipitation varies from 745 $\mathrm{mm}$ at the base to $828 \mathrm{~mm}$ at the top of the Sierra de la Ventana (Pérez \& Frangi 2000). The marked climatic seasonality is characterized by warm rainy summers and cold dry winters with 
occasional snowfall (Kristensen \& Frangi 1995). Mean minimum and maximum temperature ranges from $17-22.90$ in summer to $4-9^{\circ} \mathrm{C}$ in winter (Di Pietro et al. 2018). Based on our experience with the studied snake assemblage, snakes become inactive during winter and late autumn.

The area has very high grass and bush diversity. Native vegetation corresponds to the Austral Pampean District (Cabrera 1976), which is composed of more than 400 plant species, many of which are endemic (De la Sota 1967, Frangi \& Bottino 1995, Frangi \& Barrera 1996). Although many patches of the area have been forested with exotic trees such as Pinus sp., Cedrus sp., Acacia sp., Eucalyptus sp. and Ulmus sp., natural grasslands have greatconservation value (Bilenca \& Miñarro 2004). From the first herpetological list (Koslowsky 1895) to subsequent records (Couturier \& Grisolia 1989, Viñas et al. 1989, Di Pietro et al. 2012, 2018), a total of 25 reptile species have been reported in the region: one turtle, two amphisbaenids, seven lizards and 15 snakes. Of these, two are microendemic: the snake Lygophis elegantissimus (Koslowsky 1895) and the lizard Pristidactylus casuhatiensis (Gallardo 1968).

\section{Data collection}

Field data were collected over 15-week study periods between February 2010 and March 2014 (one in winter, two in autumn, six in spring and six in summer), with greater sampling efforts in the months when snakes were active (September to March). Snakes were handcaptured using transect surveys. Three active searchers followed 4-5 km long line-transects daily for approximately $6 \mathrm{~h}$ distributed between midmorning to late afternoon (Foster 2012). Our sampling design consisted of 2016 man-hours regularly visiting three fixed transects (Fig. 1).



Figure 1. Study area. Localities of the specimens examined (dots). Numbers indicate the fixed transects close to Cerro Cura Malal Grande (1), Ernesto Tornquist Provincial Park (2), and Villa La Arcadia village (3). 
Transect 1 (25 visits) was located in the Cerro Cura Malal Grande $\left(37.7166^{\circ} \mathrm{S}, 62.2166^{\circ} \mathrm{W}\right)$ on the Sierra de Cura Malal. Transect 2 (39 visits) passed through the protected area Ernesto Tornquist Provincial Park $\left(38.0501^{\circ} \mathrm{S}, 62.0333^{\circ} \mathrm{W}\right)$ on the Sierra de la Ventana. Transect 3 (41 visits) ran between Sierra de las Tunas and Sierra de Pillahuincó, near Villa La Arcadia village $\left(38.1284^{\circ} \mathrm{S}, 61.7751^{\circ} \mathrm{W}\right)$. In addition, nonsystematic visits to other neighboring localities were performed, totaling 672 additional manhours (Fig. 1). Each transect faithfully reflected microhabitat categories (see below) and availability within the study area.

Additional information was obtained from road-killed specimens collected during roadriding surveys (Foster 2012) in the afternoon on paved roads (Provincial Routes 51, 67, 72, 76, 85, and National Route 33), totaling $4500 \mathrm{~km}$ of active search by car (approximately $50 \mathrm{~km} / \mathrm{h}$ ). To augment field data on diet, museum specimens previously collected within the study area and housed at the Museo Argentino de Ciencias Naturales "Bernardino Rivadavia" (MACN, Buenos Aires), Museo de La Plata (MLP.JW and MLP.R, Buenos Aires) and Fundación Miguel Lillo (FML, Tucumán) were examined. Field-collected snakes and museum specimens are listed in Supplementary Material - Appendix S1. Our study does not require Ethics Committee and protocol number, only Collecting permits provided by the Organismo Provincial para el Desarrollo Sostenible, Gobierno de la Provincia de Buenos Aires (OPDS, Disposición № 003/2011), Argentina are required for this type of study.

\section{Data analyses}

Entire digestive tracts were separated from snake bodies following a mid-ventral incision from the throat to the vent opening. Individual tracts were preserved in separate capsules using $70 \%$ ethanol. Prey items were examined under a stereomicroscope to achieve better taxonomic accuracy.

Prey volume was calculated by water displacement of entire items, commonly from the esophagus or stomach (accuracy $0.01 \mathrm{ml}$ ), or by using items of the same size from partially digested prey, usually from the intestine. Some invertebrates were considered either accidentally ingested or secondary prey items because of their small size and presence in the digestive tract together with remains of anurans or lizards (Martins et al. 2002). Highly digested remains (usually from the posterior part of the intestine) were considered unidentifiable.

Data on microhabitat use were obtained only from specimens collected during fieldwork. Accordingly, microhabitats were classified into seven categories: (1) stream watercourse (specimens found swimming); (2) stream edges (specimens found with part of their body in the water and part on ground); (3) grassland with shrubs (specimens found surrounded by shrubs on grasslands, regardless of soil coverage); (4) grassland without shrubs (specimens found on a densely covered grassland substrate); (5) bare ground (specimens found on an uncovered grassland substrate); (6) on top of rocks (specimens found on firm blocks of rocks and/ or between loose rocks on a rock substrate); and (7) under rocks (specimens found under loose rocks on bare ground). The microhabitat of road-killed specimens was coded taking the surrounding road habitat into account.

Trophic diversity (Hurtubia 1973) of each individual snake was calculated using the formula of Brillouin (1962): $H=(1 / \mathrm{N})\left(\log _{2}\right.$ $\mathrm{N}$ ! $-\Sigma \log _{2} \mathrm{~N}_{\mathrm{l}}$ !); where $\mathrm{N}$ is the total number of prey found in each stomach, and $N_{i}$ the total number of prey of species $i$ found in each stomach. The accumulated trophic diversity values were calculated by random additions of the individual estimations of the trophic 
diversity of each stomach (Brillouin 1962). Each round of random additions integrated the prey items of all previous stomachs for which trophic diversity was calculated. Then, the accumulated trophic diversity values were plotted versus the stomach number to estimate the minimum sample for each species (i.e., when values turned asymptotic; Hurtubia 1973, Basso 1990). The formula of Brillouin (1962) was also employed to estimate the diversity of prey and microhabitat used by each species, where $\mathrm{N}$ was the total number of prey or specimens, and $N_{i}$ the total number of prey of species $i$ or specimens in microhabitat $i$, as applicable.

The degree of utilization of available resources in the environment was calculated by the evenness or equitability index of Pielou (1969): J' = $H^{\prime} / H_{\text {Maxi }}^{\prime}$; being $H^{\prime}=-\Sigma P_{i} \log _{2} P_{i}$ and $H_{\text {Max }}^{\prime}=\log _{2} S$; where $H^{\prime}$ is the Shannon index (Shannon \& Weaver 1949), $P_{i}$ the proportion of prey of species $i$ or specimens in microhabitat $i$, and $\mathrm{S}$ the number of prey items consumed or microhabitats used, as appropriate. The importance of each prey item in the diet of the species was estimated using the importance index based on pooled stomachs (Biavati et al. 2004), as follows: IPS = (F\% + N\% + V\%) / 3; where $\mathrm{F} \%$ is the occurrence percentage of each prey item, $\mathrm{N} \%$ the numerical percentage of each prey item and V\% the volumetric percentage of each prey item. Niche breadth of prey number, prey volume, and microhabitat use were calculated using the index proposed by Levins (1968): $\mathrm{Nb}=$ $\left(\Sigma p_{i j}{ }^{2}\right)^{-1}$; where $p_{i j}$ represents the probability of finding each prey item $i$ in sample $j$ or species $i$ in microhabitat $j$, as applicable.

Diet (prey proportion and volume) and microhabitat use overlaps were calculated using the overlap index of Pianka (1973): $\mathrm{O}_{\mathrm{jk}}=$ $\Sigma \mathrm{p}_{\mathrm{ij}} \mathrm{p}_{\mathrm{ik}} /\left(\Sigma \mathrm{p}_{\mathrm{ij}}^{2} \Sigma \mathrm{p}_{\mathrm{ik}}^{2}\right)^{1 / 2}$; where $\mathrm{p}_{\mathrm{ij}}$ and $\mathrm{p}_{\mathrm{ik}}$ are the proportions of resource utilization by species. The overlap index ranges from 0 to 1 . Values near 1 mean increasing similarity in diet or microhabitat (complete overlap), whereas values near 0 indicate dissimilarity (absence of overlap). As already mentioned, two of the three dimensions of the ecological niche (diet and habitat) were assessed. The temporal dimension was excluded since most authors consider it is less important in structuring herpetological assemblages (Schoener 1974, Pianka 1974, Toft 1985). Overlap values were studied by randomization analysis to evaluate differences between observed and expected values using EcoSim version 7.71 (Gotelli \& Entsminger 2004), which creates random assemblages of observed data with a Monte Carlo simulation. The RA3 algorithm (retained niche breadth/reshuffled zero states) with 1000 randomizations of the original data (Winemiller \& Pianka 1990) was used for the analysis.

Diet and microhabitat use overlap between each pair of species was also estimated with the asymmetrical overlap index of MacArthur \& Levins (1967): $M_{i y}=\Sigma P_{i} P_{y} / \Sigma P_{i y}{ }^{2}$; where $P_{i}$ and $P_{y}$ are the proportions of resource utilization by species. The index provides two values of overlapping (incidence of species $i$ over $y$ and incidence of species $y$ over i) and is therefore more informative than the symmetrical overlap index of Pianka (1973).

Finally, three morphological measurements, namely, Total Length ( $T L)$, Mouth Width (MW), and Mass (M) were obtained from each studied specimen, excepting MW in Epictia australis. Trophic behavioral features (e.g., degree of prey selection) within species were described by correlations of TL and MW with mean volume of ingested prey using Pearson's $r$ with PAST software (version 3.04; Hammer et al. 2001). 


\section{RESULTS}

A total of 15 snake species were recorded. Of these species, only five were abundant enough for analyses (Fig. 2): Epictia australis (Leptotyphlopidae), Erythrolamprus poecilogyrus, Lygophis elegantissimus, Philodryas patagoniensis (Colubridae, Dipsadinae), and Bothrops alternatus (Viperidae, Crotalinae). Other species recorded were Epictia munoai (Leptotyphlopidae), Lygophis anomalus, Oxyrhopus rhombifer, Paraphimophis rusticus, Phalotris bilineatus, Philodryas aestiva, Philodryas agassizii, Xenodon dorbignyi, Xenodon semicinctus (Colubridae, Dipsadinae), and Bothrops ammodytoides (Viperidae, Crotalinae). Voucher information of each species is shown in Appendix S1, and additional information on diet composition of the whole snake assemblage is presented in Table SI.

\section{Prey resource use}

\section{Epictia australis}

Eighteen (36.73\%) of the dissected specimens contained identifiable prey in their digestive tracts, exceeding the minimum sample size of this species (Table I; Fig. 2a). They fed exclusively on all age classes of the ant genus Pheidole. The IPS values indicated that ant eggs and larvae were the most important prey (Table II). As most scolecophidians, this species was a dietary specialist, as indicated by low and not very equitable values of prey diversity and a narrow trophic niche breadth (Table I). Mean TL and $M$ values were much lower than those of the other species studied (Table I). The correlation between prey volume and TL was not significant $(r=0.001, p=1)$.

\section{Erythrolamprus poecilogyrus}

More than half (58.14\%) of the specimens examined had digestive tracts with identifiable contents, which exceeded the minimum sample size of the species (Table I; Fig. 2b). Larvae of the bufonid toad Rhinella arenarum was the most important of the nine prey types found in the diet of E. poecilogyrus (Table II). Prey diversity was relatively high and fairly equitable, with higher values of trophic niche breadth (Table I). The correlation of prey volume with $\mathrm{MW}(r=$
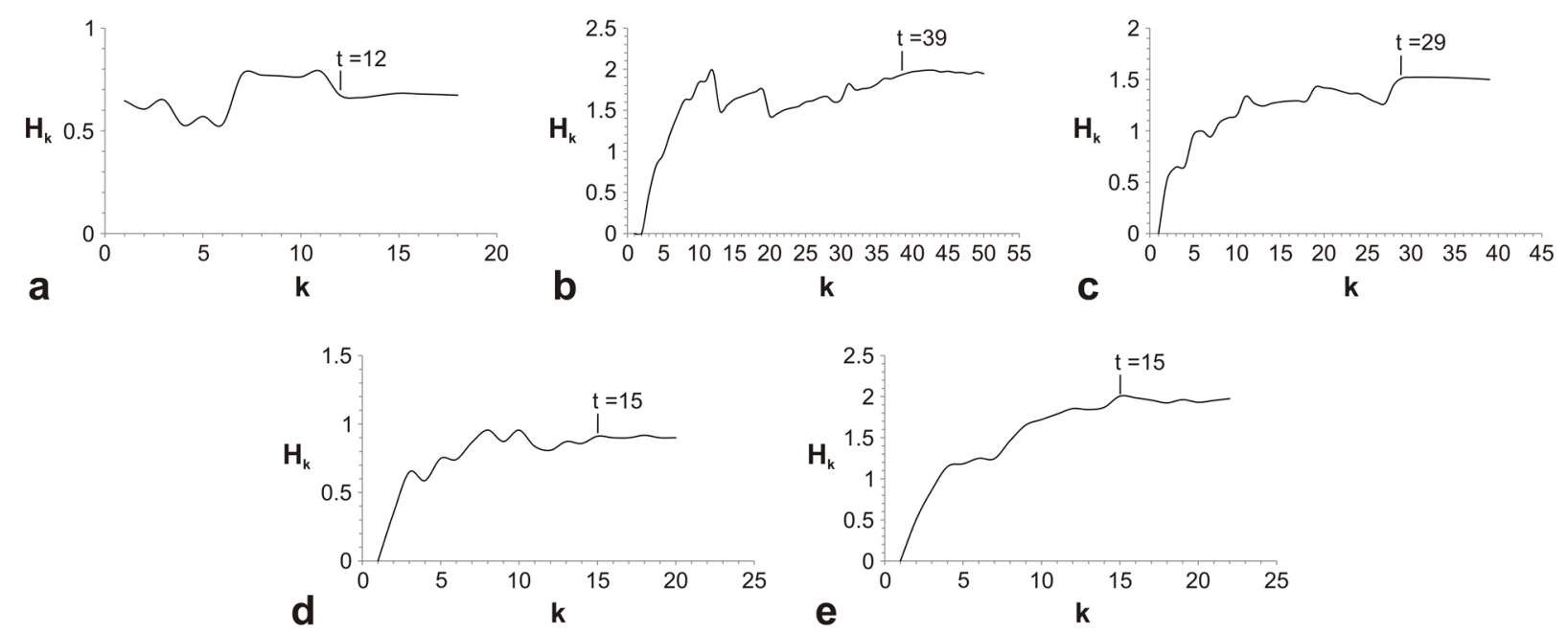

Figure 2. Minimum sample size determination for Epictia australis (a), Erythrolamprus poecilogyrus (b), Lygophis elegantissimus (c), Philodryas patagoniensis (d), and Bothrops alternatus (e). $\mathrm{Hk}=$ accumulated trophic diversity, $\mathrm{k}$ = number of stomachs, $\mathrm{t}=$ minimum sample size. 
Table I. Field-collected (alive in field, Af; road-killed, Rk) and museum collection (Mc) specimens, and their morphological measurements (mean total length in $\mathrm{mm}$, $\mathrm{TL}$; mean mass in $\mathrm{g}, \mathrm{M}$; mean mouth width in $\mathrm{mm}, \mathrm{MW}$ ). The table shows the values of diversity $(\mathrm{H})$, equitability index ( $\left.\mathrm{J}^{\prime}\right)$, and niche breadth $(\mathrm{Nb})$ for microhabitat use, prey number (N) and prey volume (V) categories. See text for details of calculations. Ea = Epictia australis, Ep $=$ Erythrolamprus poecilogyrus, Le $=$ Lygophis elegantissimus, $\mathrm{Pp}=$ Philodryas patagoniensis, $\mathrm{Ba}=$ Bothrops alternatus.

\begin{tabular}{|c|c|c|c|c|c|c|c|c|c|c|c|c|}
\hline & \multicolumn{4}{|c|}{ Specimens } & \multicolumn{3}{|c|}{ Morphometric } & \multicolumn{4}{c|}{ Prey } & \multicolumn{3}{c|}{ Microhabitat } \\
\hline Species & Af & $\mathbf{R k}$ & $\mathbf{M c}$ & $\mathbf{T L}$ & $\mathbf{M}$ & $\mathbf{M W}$ & $\mathbf{H}$ & $\mathbf{J}$ & $\mathbf{N b}$ (N/V) & $\mathbf{H}$ & $\mathbf{J}$ & $\mathbf{N b}$ \\
\hline $\mathrm{Ea}$ & 18 & 0 & 31 & 152.29 & 1.50 & - & 0.67 & 0.44 & $1.32 / 1.32$ & 0.46 & 0.39 & 1.26 \\
\hline $\mathrm{Ep}$ & 37 & 6 & 43 & 472.64 & 42.09 & 10.80 & 1.95 & 0.65 & $3.09 / 5.48$ & 1.79 & 0.87 & 3.38 \\
\hline $\mathrm{Le}$ & 24 & 5 & 41 & 513.16 & 27.04 & 9.70 & 1.49 & 0.72 & $2.67 / 2.55$ & 1.86 & 0.79 & 3.77 \\
\hline $\mathrm{Pp}$ & 10 & 6 & 27 & 720.07 & 105.72 & 13.69 & 0.95 & 0.54 & $1.62 / 2.69$ & 1.18 & 0.75 & 2.37 \\
\hline $\mathrm{Ba}$ & 11 & 9 & 38 & 774.04 & 259.84 & 25.24 & 1.98 & 0.88 & $4.57 / 4.12$ & 1.62 & 0.79 & 3.33 \\
\hline
\end{tabular}

-0.079, $p=0.585)$ and $T L(r=-0.001, p=0.996)$ was not significant.

\section{Lygophis elegantissimus}

The analysis of 70 specimens of this endemic snake showed that $55.71 \%$ presented identifiable contents in their digestive tracts, which exceeded the estimated minimum sample size (Table I; Fig. 2c). The diet of this species was similar to that of E. poecilogyrus, but more specialized in anurans. Five prey items were detected; they were all anurans and the most important was the hylid frog Boana pulchella (Table II). Prey diversity was low and fairly equitable, with relatively low values of trophic niche breadth (Table I). Prey volume significantly correlated with MW ( $r=$ 0.393, $p=0.015)$ and $T L(r=0.638, p=0.001)$.

\section{Philodryas patagoniensis}

Forty-three specimens were dissected; of these, $46.51 \%$ had identifiable contents in their digestive tracts, exceeding the estimated minimum sample (Table I; Fig. 2d). The diet of this species consisted of four prey types, with spiders (Lycosa sp.) being the most important (Table II). Prey diversity was low and not very equitable, with low values of trophic niche breadth (Table I). The correlation of prey volume with MW $(r=0.461, p=0.041)$ and $T L(r=0.541, p$ $=0.014)$ was significant.

\section{Bothrops alternatus}

From 58 stomachs dissected, 37.93\% presented identifiable contents, exceeding the minimum sample size (Table I; Fig. 2e). The diet of $B$. alternatus included seven prey items; they were all rodents and Necromys benefactus was the most important (Table II). Prey diversity was high and very equitable, with high values of trophic niche breadth (Table I). Bothrops alternatus was the largest species studied (Table I). A significant correlation was found between prey volume and $\mathrm{TL}(r=0.507, p=0.016)$, but not between prey volume and $\mathrm{MW}(r=0.361, \mathrm{p}=0.099)$.

\section{Microhabitat Use}

\section{Epictia australis}

Data on only $36.73 \%$ of specimens from the total sample were recorded during fieldwork (Table I). Despite specimens were restricted to three microhabitats, the vast majority of individuals were found under rocks (Fig. 3a). Microhabitat use diversity was low, not equitable and with low values of spatial niche breadth (Table I). 







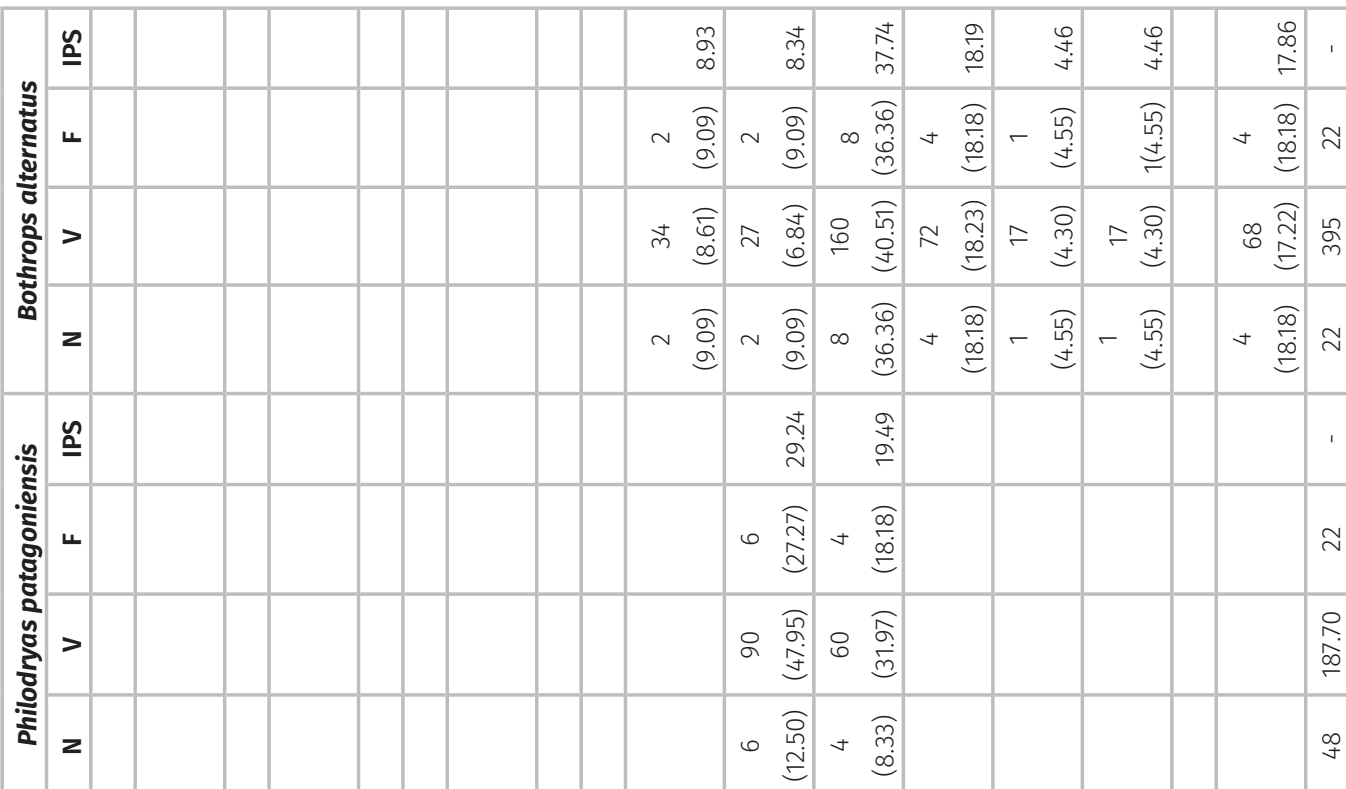

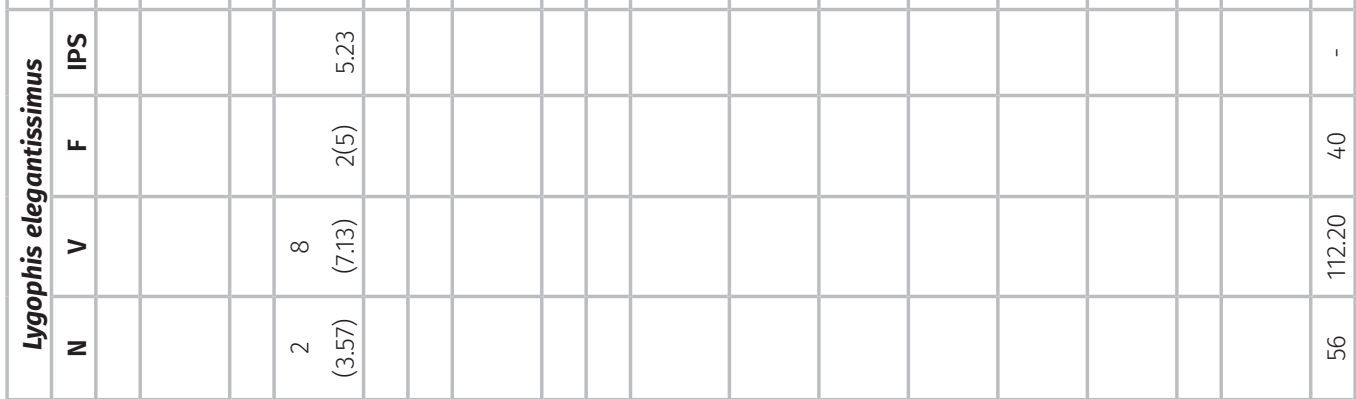

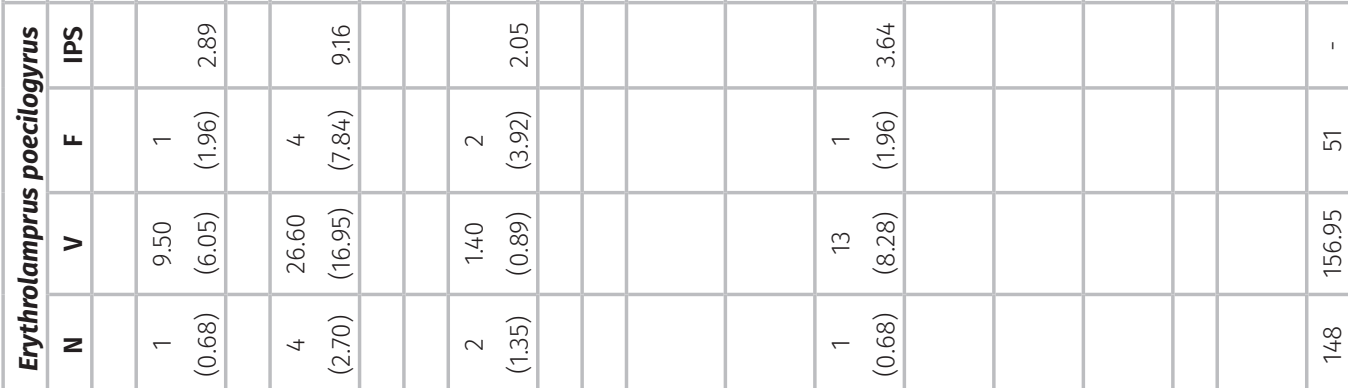

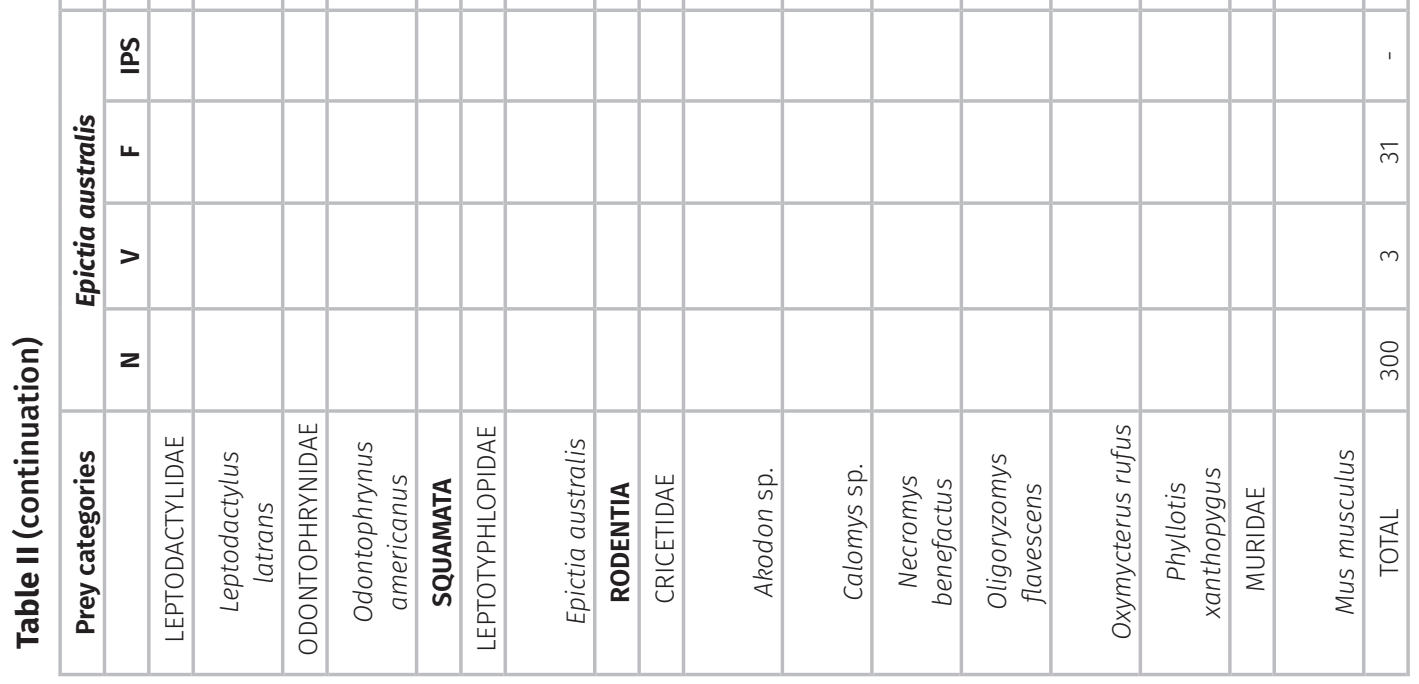



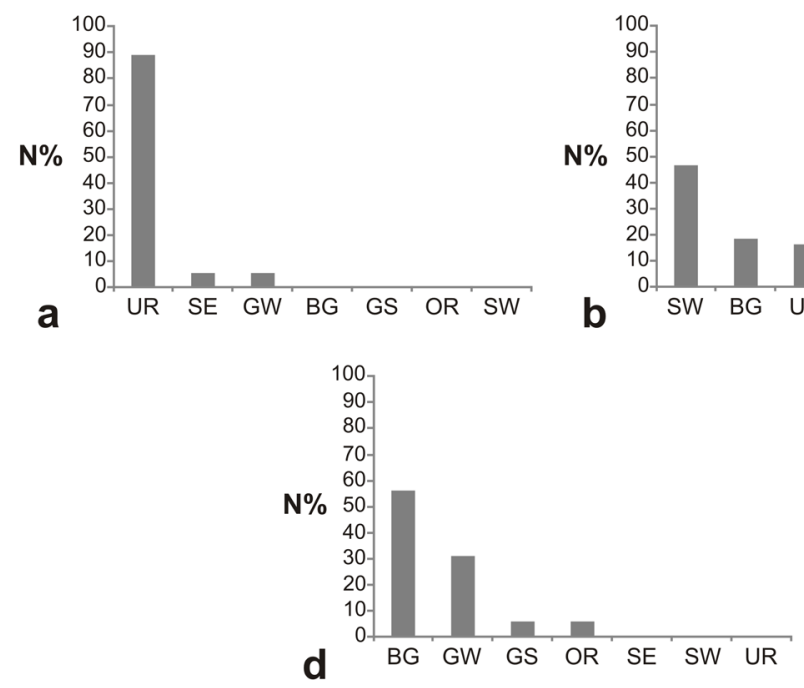
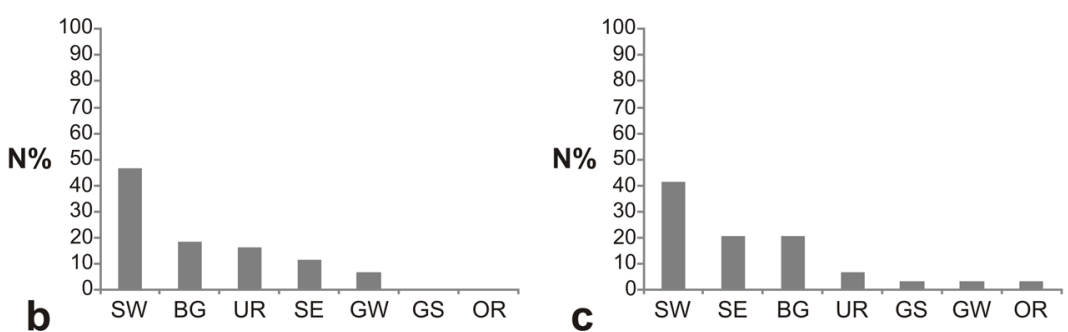

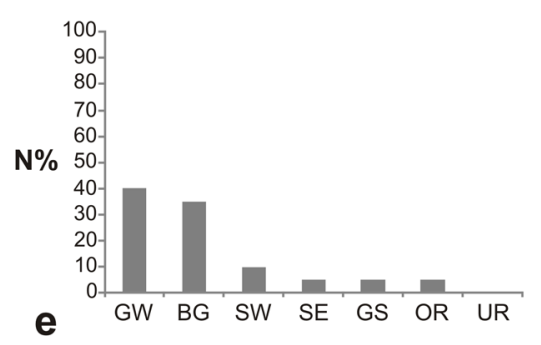

Figure 3. Microhabitats used by Epictia australis (a), Erythrolamprus poecilogyrus (b), Lygophis elegantissimus (c), Philodryas patagoniensis (d), and Bothrops alternatus (e). N\% = percentage of specimens, SW = stream watercourse, $\mathrm{SE}=$ stream edges, GS = grassland with shrubs, GW = grassland without shrubs, BG = bare ground, OR = on top of rocks, UR = under rocks.

\section{Erythrolamprus poecilogyrus}

Data from $50 \%$ of the total specimens were recorded (Table I). This species was found in five of the seven microhabitat categories, mainly stream watercourses and bare grounds (Fig. 3b). Microhabitat use diversity was high and very equitable, with high values of spatial niche breadth (Table I).

\section{Lygophis elegantissimus}

Data on $41.43 \%$ of the total sample were recorded during fieldwork (Table I). This was the only species that used all seven microhabitat categories, mainly stream watercourses and stream edges (Fig. 3C). Microhabitat use diversity was high and very equitable, with high values of spatial niche breadth (Table I).

\section{Philodryas patagoniensis}

Of the total sample, $37.21 \%$ of specimens were found in four types of microhabitats, particularly bare grounds and grassland without shrubs (Table I; Fig. 3d). Microhabitat use diversity was low and very equitable, with relatively low values of spatial niche breadth (Table I).

\section{Bothrops alternatus}

Only $34.48 \%$ of specimens were recorded during fieldwork (Table I). This species used almost all microhabitats (mainly grassland without shrubs and bare grounds) with the exception of under rocks (Fig. 3e). Microhabitat use diversity was relatively low and very equitable, with relatively high values of spatial niche breadth (Table I).

\section{Trophic and spatial relationships}

Our results support the partitioning of the snake assemblage by both habitat use and diet into at least three functional groups: (1) species restricted to the microhabitat under rocks and with a diet composed exclusively of ants (Epictia australis), (2) species found mostly in stream microhabitats and feeding mainly upon anurans (Erythrolamprus poecilogyrus and Lygophis elegantissimus), and (3) species found mostly in grassland microhabitats, with specialized diets of terrestrial prey items (Philodryas patagoniensis 
and Bothrops alternatus). The relationship of overlap values between two trophic variables (proportion and volume of prey) and microhabitat use of the five species studied is shown in Table III. Random combinations of prey proportion information produced low overlap values, which were significant in eight of the 10 species pairs, whereas random combinations of prey volume data produced significantly low overlap values in six of the 10 species pairs. Microhabitat use randomization showed significantly high overlap in only two species pairs (Table III).

Results obtained by the asymmetrical overlap index of MacArthur \& Levins (1967) are shown in Table IV. Under resource scarcity, significantly high microhabitat use overlap values indicated that E. poecilogyrus was likely to be affected by $L$. elegantissimus, and P. patagoniensis was likely to be affected by $B$. alternatus.

\section{DISCUSSION}

We reportthe most in-depth and detailed analysis of diet, feeding strategies and microhabitat use of five species from a snake assemblage in the Sierras de Ventania low mountain chain. Our data support the partitioning of the assemblage into at least three groups by habitat use and diet. The first group was composed of Epictia australis, the smallest snake of the assemblage. It was an active forager feeding exclusively upon ants and almost entirely restricted to microhabitats beneath rocks. The second group was composed of two medium-sized dipsadine species, Erythrolamprus poecilogyrus and Lygophis elegantissimus. Both species used riparian microhabitats more than other environments; they were active foragers and fed mainly ( $E$. poecilogyrus) or exclusively (L. elegantissimus) upon anurans. The third group consisted of the largest species of the assemblage, Philodryas patagoniensis and Bothrops alternatus, which were found in grassland microhabitats and fed on terrestrial prey obtained by active (mainly spiders by P. patagoniensis) or passive (exclusively rodents by B. alternatus) foraging strategies.

Table III. Pairwise interspecific relationships of species within the snake assemblage from the Sierras de Ventania in east-central Argentina. Overlap values of Pianka (1973) $\left(O_{j k}\right)$, overlap significance $\left(P_{o \geq e} ; P_{o \leq e}\right)$, observed mean $\left(\bar{x}_{\mathrm{obs}}\right)$ and expected mean $\left(\bar{x}_{\exp }\right)$ of three traits: prey proportion, prey volume, and microhabitat use. Significant values $(p \leq 0.05)$ are shown in bold. See text for details of calculations. Other references as in Table I.

\begin{tabular}{|c|c|c|c|c|c|c|c|c|c|c|c|c|c|c|c|}
\hline \multirow[b]{2}{*}{ Species } & \multicolumn{5}{|c|}{ Prey proportion } & \multicolumn{5}{|c|}{ Prey volume } & \multicolumn{5}{|c|}{ Microhabitat } \\
\hline & $O_{j k}$ & $P_{0 \geq e}$ & $P_{0 \leq e}$ & $\bar{x}_{o b s}$ & $\bar{x}_{\exp }$ & $\mathrm{O}_{\mathrm{jk}}$ & $P_{0 \geq e}$ & $P_{0 \leq e}$ & $\bar{x}_{o b s}$ & $\overline{\mathbf{x}}_{\exp }$ & $O_{j k}$ & $P_{0 \geq e}$ & $P_{0 \leq e}$ & $\overline{\mathrm{x}}_{\mathrm{obs}}$ & $\overline{\mathrm{X}}_{\mathrm{exp}}$ \\
\hline Ea-Ep & 0 & 1 & 0.01 & 0 & 0.17 & 0 & 1 & 0.01 & 0 & 0.29 & 0.32 & 0.57 & 0.43 & 0.32 & 0.42 \\
\hline Ea-Le & 0 & 1 & 0.02 & 0 & 0.24 & 0 & 1 & 0.02 & 0 & 0.37 & 0.16 & 0.56 & 0.44 & 0.16 & 0.32 \\
\hline Ea-Pp & 0 & 1 & 0.03 & 0 & 0.22 & 0 & 1 & 0.02 & 0 & 0.36 & 0.03 & 0.91 & 0.09 & 0.03 & 0.29 \\
\hline $\mathrm{Ea}-\mathrm{Ba}$ & 0 & 1 & 0.01 & 0 & 0.25 & 0 & 1 & 0.01 & 0 & 0.46 & 0.05 & 0.91 & 0.09 & 0.05 & 0.29 \\
\hline Ep-Le & 0.25 & 0.40 & 0.59 & 0.25 & 0.27 & 0.17 & 0.73 & 0.28 & 0.17 & 0.34 & 0.96 & 0.01 & 0.99 & 0.96 & 0.51 \\
\hline Ep-Pp & 0.01 & 0.99 & 0.01 & 0.01 & 0.18 & 0.52 & 0.18 & 0.82 & 0.52 & 0.26 & 0.36 & 0.52 & 0.48 & 0.36 & 0.41 \\
\hline $\mathrm{Ep}-\mathrm{Ba}$ & 0.01 & 0.99 & 0.01 & 0.01 & 0.26 & 0.32 & 0.57 & 0.43 & 0.32 & 0.36 & 0.49 & 0.41 & 0.59 & 0.49 & 0.49 \\
\hline Le-Pp & 0 & 1 & 0.01 & 0 & 0.23 & 0 & 1 & 0.01 & 0 & 0.29 & 0.39 & 0.56 & 0.45 & 0.39 & 0.43 \\
\hline Le-Ba & 0 & 1 & 0.01 & 0 & 0.29 & 0 & 1 & 0.01 & 0 & 0.36 & 0.50 & 0.47 & 0.53 & 0.50 & 0.52 \\
\hline $\mathrm{Pp}-\mathrm{Ba}$ & 0.11 & 0.79 & 0.21 & 0.11 & 0.29 & 0.52 & 0.47 & 0.53 & 0.52 & 0.44 & 0.92 & 0.05 & 0.95 & 0.92 & 0.46 \\
\hline
\end{tabular}


Table IV. Overlap values of MacArthur \& Levins (1967) for prey proportion, prey volume and microhabitat use. Significant species pairs are shown in bold. See text for details of calculations. Other references as in Table I.

\begin{tabular}{|c|c|c|c|}
\hline Species & $\begin{array}{c}\text { Prey } \\
\text { proportion }\end{array}$ & $\begin{array}{c}\text { Prey } \\
\text { volume }\end{array}$ & Microhabitat \\
\hline Ea-Ep & $\mathbf{0}$ & $\mathbf{0}$ & 0.19 \\
\hline Ep-Ea & $\mathbf{0}$ & $\mathbf{0}$ & 0.52 \\
\hline Ea-Le & $\mathbf{0}$ & $\mathbf{0}$ & 0.09 \\
\hline Le-Ea & $\mathbf{0}$ & $\mathbf{0}$ & 0.28 \\
\hline Ea-Pp & $\mathbf{0}$ & $\mathbf{0}$ & 0.02 \\
\hline Pp-Ea & $\mathbf{0}$ & $\mathbf{0}$ & 0.04 \\
\hline Ea-Ba & $\mathbf{0}$ & $\mathbf{0}$ & 0.03 \\
\hline Ba-Ea & $\mathbf{0}$ & $\mathbf{0}$ & 0.08 \\
\hline Ep-Le & 0.27 & 0.11 & $\mathbf{0 . 9 1}$ \\
\hline Le-Ep & 0.23 & 0.27 & $\mathbf{1 . 0 1}$ \\
\hline Ep-Pp & $\mathbf{0 . 0 1}$ & 0.62 & 0.43 \\
\hline Pp-Ep & $\mathbf{0 . 0 1}$ & 0.43 & 0.29 \\
\hline Ep-Ba & $\mathbf{0 . 0 1}$ & 0.83 & 0.49 \\
\hline Ba-Ep & $\mathbf{0 . 0 1}$ & 0.13 & 0.48 \\
\hline Le-Pp & $\mathbf{0}$ & $\mathbf{0}$ & 0.49 \\
\hline Pp-Le & $\mathbf{0}$ & $\mathbf{0}$ & 0.31 \\
\hline Le-Ba & $\mathbf{0}$ & $\mathbf{0}$ & 0.53 \\
\hline Ba-Le & $\mathbf{0}$ & $\mathbf{0}$ & 0.47 \\
\hline Pp-Ba & 0.07 & 1.11 & $\mathbf{0 . 7 8}$ \\
\hline Ba-Pp & 0.19 & 0.24 & $\mathbf{1 . 0 9}$ \\
\hline
\end{tabular}

The strict myrmecophagous diet of Epictia australis has been previously described in related and phylogenetically distant leptotyphlopids such as Epictia munoai (Vaz Ferreira et al. 1970, Carreira 2002) and Leptotyphlops scutifrons (Webb et al. 2000), respectively. Our finding that diet overlap in E. australis was low compared with other snakes was not surprising in light of the distant phylogenetic relationship between scolecophidians and alethinophidians (Vitt \& Pianka 2005, Zheng \& Wiens 2016). Indeed, as our understanding of phylogenetic relationships among scolecophidians improved, that of variations in foraging mode among scolecophidian lineages also improved. Surprisingly, and based only on the five species which exceeded the minimum sample size, E. australis had the highest proportion of empty stomachs, considering that many scolecophidians are thought to feed at a much higher frequency than other snakes. The shift of scolecophidians from lizard-like (feeding frequently on small prey) to snake-like (feeding infrequently on large prey) trophic biology is evident (Webb et al. 2000). For instance, two species of North American leptotyphlopids (Rena humilis and Rena dulcis) feed frequently on taxonomically diverse small prey (Punzo 1974); the African L. scutifrons, several Australian typhlopids and the South American E. australis feed infrequently on taxonomically restricted small prey, but have large meals composed of numerous prey items (Shine \& Webb 1990, Webb \& Shine 1993, Webb et al. 2000, this study); finally, the highly derived Melanesian typhlopid Acutotyphlops subocularis fed infrequently on large elongate prey (Webb et al. 2000). Thus, in contrast to popular theory (Greene 1983, 1997), our data also support the idea that the evolutionary shift to infrequent feeding among snakes did not initially require a change from small to large prey.

The diet of scolecophidians is consistent with active foraging. Such predators capture many small prey items with potentially highenergy costs for both prey detection and digestion, which is balanced out by the lowenergy cost of capture (Toft 1980, 1981, 1985, Huey \& Pianka 1981). Since ants live in large colonies, they represent a sedentary resource usually found in large numbers, clustered in both space and time that only active foragers may use (Gerritsen \& Strickler 1977, Krebs 1978, Eckhardt 1979, Huey \& Pianka 1981, Basso 
1990). According to our results, the absence of correlation between volume of ingested prey and snake size indicated that both juvenile and adult $E$. australis consumed prey of similar size. Two steps in prey detection by active foragers are recognized in the literature. First, the snake detects the prey using its vomeronasal organ and then, the snake manages to catch the prey by sight (Greene 1997, Mullin \& Cooper 1998). Although E. australis forages actively, it has reduced eyes and probably relies on chemosensory and tactile cues to detect and locate prey, and on morphological adaptations for rapid handling to subdue and consume their prey (Kley 2001).

The diet of Erythrolamprus poecilogyrus was mainly composed of adult and larval anurans and fish, which were preyed upon using active foraging tactics. Previous studies have categorized E. poecilogyrus as either a dietary generalist (Serié 1919, Gallardo 1977, Lema et al. 1983, Michaud \& Dixon 1989, Cei 1986, 1993) or an anuran specialist (Vitt 1983, Vitt \& Vangilder 1983, Dixon \& Markezich 1992, Pinto \& Fernandes 2004). A third, intermediate position that best matches our results suggests that $E$. poecilogyrus tends to feed on anurans but also consumes other types of prey (Carreira 2002, Prieto et al. 2012). In our study, the size of the prey ingested by E. poecilogyrus was not correlated with the size of the snakes, considering that small snakes could swallow large prey and large snakes did not reject small prey. This agrees with the proposal of Shine (1987), who hypothesized that active foragers would consume any prey they encountered, including small prey, because the time, costs, risk and energy necessary to catch and swallow prey would be trivial (Schoener 1977, Pough \& Andrews 1985).

Lygophis elegantissimus exclusively fed upon anurans, mainly larvae and adult Boana pulchella. These results partially agree with previous reports that included anurans, as well as lizards on the diet of this species (Miranda et al. 1983, Williams \& Scrocchi 1994). However, we did not document any lizards in L. elegantissimus digestive tracts, despite their abundance in the study area. Dietary studies of other Lygophis species also highlighted the importance of anurans in the diet of these snakes (Vitt 1983, Vitt \& Vangilder 1983, Michaud \& Dixon 1989, Carreira 2002, Panzera \& Maneyro 2014), which may be an ancestral trait within Xenodontinae (Cadle \& Greene 1993). Thus, we characterized L. elegantissimus as a specialist with relatively low prey diversity and a narrow trophic niche, as expected for active foragers (Toft 1980, 1981, Huey \& Pianka 1981, Perry \& Pianka 1997). In contrast to E. poecilogyrus, L. elegantissimus could consume larger prey as they increase in size.

Many active predators employ bright coloration for predator deterrence. In our study, both E. poecilogyrus and L. elegantissimus preyed upon adult Melanophryniscus aff. montevidensis (see taxonomic comments in Vaira et al. 2012), a highly noxious bufonid toad that uses skin alkaloids for self-defense (Daly et al. 2008) and exhibits aposematic coloration and unken reflex behavior. The current data increase the knowledge of snake predation upon these toads, suggesting that bright coloration may be aposematic. Other snake predators of Melanophryniscus include Thamnodynastes strigatus, feeding on M. moreirae in Brazil (Winkler et al. 2011), and Xenodon dorbignyi, feeding on M. montevidensis and M. atroluteus in Uruguay (Orejas Miranda 1966). Adult Rhinella arenarum, a toad which also produces toxic secretions (Mebs 2002), was also recorded in the digestive tracts of L. elegantissimus. In contrast to Melanophryniscus, toads of the genus Rhinella are commonly preyed on by several snakes in the genera Erythrolamprus, 
Lygophis and Xenodon (Michaud \& Dixon 1989, Oliveira et al. 2001, Pinto \& Fernandes 2004, Albarelli \& Santos Costa 2010, Prieto et al. 2012, Panzera \& Maneyro 2014). Recently, documented patterns of alkaloid resistance mechanisms within diverse South American snake and toad radiations (Mohammadi et al. 2016) could help discover additional examples of toxin sequestration in snakes (Savitzky et al. 2012). Our findings suggest that L. elegantissimus and E. poecilogyrus could be regarded as potentially promising candidates.

The diet of Philodryas patagoniensis was mostly made up of spiders of the genus Lycosa (77.08\%) followed by rodents (20.83\%), thus, representing low prey diversity and a relatively narrow trophic niche. This species has been reported as a generalist whose diet varied geographically in response to variations in prey assemblages (Gallardo 1977, Cei 1986, 1993, Gonzaga et al. 1997, Carreira 2002, López 2003, Hartmann \& Marques 2005, López \& Giraudo 2008). For example, Lema (1973) suggested that $P$. patagoniensis preyed upon almost any available prey, and Carreira (2002) found several arthropods (mainly spiders of the genus Lycosa) in the gastric contents of $P$. patagoniensis from Uruguay. Despite other authors have reported the ingestion of amphibians by specimens from Uruguay and Brazil and reptile predation by specimens from northern Argentina (Carreira 2002, Hartmann \& Marques 2005, López \& Giraudo 2008), we did not find amphibians or reptiles in the digestive tracts of $P$. patagoniensis. The species thus would be generalist in a broad sense (across entire species range), although our study population specialized in preying upon spiders and rodents. Furthermore, the significant correlation between volume of ingested prey and snake size showed that the species could consume large prey in response to increments in body size, but did not cease the ingestion of small prey. The high frequency of consumption of such prey would indicate an active rather than a passive foraging strategy (Toft 1980, 1981, 1985), like most colubrid snakes do (Luiselli 2006). Spiders of the genus Lycosa are also the primary prey of $P$. agassizii (Viñas 1985, Carreira 2002, Marques et al. 2006), the sister species of $P$. patagoniensis (Zaher et al. 2009), indicating a probable phylogenetic root for this feeding preference. Arachnids are rarely preyed on by snakes, although they are regular components of the diets of a few other species (Plummer 1981, Colston et al. 2010). All spiders have venom, and $P$. agassizii apparently has both behavioral and venomic adaptations that aid it in subduing and consuming spiders without injury (Marques et al. 2006). It remains to be seen whether P. patagoniensis shares these adaptations, an expected fact given the close phylogenetic relationships between them.

As most adult viperids, the venomous Bothrops alternatus had a specialized diet of rodents, but it also consumed a great diversity of mouse species, thus showing a wide trophic niche. Previous reports have also found an exclusively mammal-based diet of this species (Cei 1986, 1993, Martins et al. 2002, Giraudo et al. 2008), probably shared by all species within the B. alternatus clade (Martins et al. 2002). Ontogenetic shifts in venom chemistry and foraging strategy have been lost in this species which, together with a large adult body size, are consistent with a lifelong diet of rodents (Andrade \& Abe 1999, Giraudo et al. 2008, Eskew et al. 2009). Luiselli (2006) pointed out that viperid snakes were generally passive foragers, using sit-and-wait tactics to obtain few prey of a large size, with low energy costs of both search and digestion, but increased time spent on capture (Toft 1980, 1981, Huey \& Pianka 1981). Essentially, all adult vipers have cryptic coloration, employ chemoreception to select ambush sites and use 
thermoreception to detect the passage of prey (Clark2004, Colston et al. 2010). The same applies to other species of Bothrops, such as B. jararaca and B. insularis (Sazima 1992, Wüster et al. 2005). Moreover, the significant correlation between snake body size and volume of consumed prey indicated that the species tended to consume large prey in response to size increases, which is consistent with predictions for vipers (Greene 1992, Forsman \& Shine 1997, Martins et al. 2002).

In general, worldwide studies dealing with habitat preferences of snakes are scarce. In fact, most species have never been investigated (Reinert 1993) and studies were often constrained by sampling biases that complicated interpretations and comparisons (Martins \& Oliveira 1998). In this context, our study is surely not an exception. Our findings agree with data in the literature (Henderson \& Binder 1980, Reinert 1993, Hartmann \& Marques 2005) in the sense that the primary correlate of microhabitat would be the local availability of prey. Thus, E. australis eats ants and is mostly found near ant mounds; E. poecilogyrus and L. elegantissimus ate fish and amphibians and were mostly found along streams; and P. patagoniensis and B. alternatus ate terrestrial prey and were mostly found in grasslands.

Epictia australis was mostly found under rocks, a valid generalization about most scolecophidians (Cei 1986, 1993). In addition, multiple individuals of different sizes were sometimes found together under the same rock, as reported in other species of the genus such as E. munoai (Vega \& Bellagamba 1990) and E. diaplocia (Martins \& Oliveira 1998). Thus, the current evidence indicates that E. australis displayed high microhabitat selectivity and feeding specialization, potentially excluding itself from competition with other snakes of the studied assemblage. Nevertheless, the ancient dietary shift of scolecophidians and alethinophidians would reveal that many modern species eat their ancestral food, regardless of habitat or biogeography (Colston et al. 2010). The potential role of competition in the structure of local assemblages has been assessed in North American snakes via comparisons between local assemblage composition and regional species pool (Burbrink \& Myers 2015). These authors demonstrated that phylogenetic variability and ecological traits were disconnected at regional level, but local assemblage compositions were better explained by certain ecological key traits, regardless of phylogeny. Similar analyses of South American snake assemblages should be encouraged.

Erythrolamprus poecilogyrus was found along mountain streams and their edges (58.14\%), as incidentally reported by other authors (Koslowsky 1895, Gallardo 1977, Miranda et al. 1983). Apparently, the species preferred streams but it was also found in several other microhabitats, as observed by Vega \& Bellagamba (1990) in a population from the Sierras de Tandilia, Argentina. Such wide use of habitat possibilities made the species a habitat generalist with a tendency to use riparian habitats, which was even more pronounced in Lygophis elegantissimus (62.07\%) than in E. poecilogyrus. Lygophis elegantissimus was found to a lesser extent in other microhabitats, as suggested by Williams \& Scrocchi (1994). Thus, this endemic species was moderately selective, supporting predictions as habitat generalist but with a trend towards the use of stream-related microhabitats. Previous studies have shown that other semi-aquatic snake species foraging in dynamic aquatic habitats could experience seasonal shifts in diet and habitat use in relation to shifts in prey availability (Hampton \& Ford 2007, Durso et al. 2013). We consider that these shifts did not operate in species of the currently studied assemblage since they were active in 
a brief period (mid spring - late summer) and became inactive the rest of the year.

Philodryas patagoniensis was found almost exclusively in grasslands (93.75\%), particularly on bare ground, regardless of the collection site (alive or road-killed; Table I). Although common and widespread throughout south-eastern South America, data on microhabitat use of this species are scarce, notwithstanding a few miscellaneous comments (Gallardo 1970, 1977, Vega \& Bellagamba 1990, Hartmann \& Marques 2005). These authors agreed on the preference of this species for open grasslands, which are also favored by rodents and lycosid spiders (Pardiñas et al. 2004, Jocqué \& Alderweireldt 2005). Similarly, our data suggest that $P$. patagoniensis was highly adapted to grasslands.

Bothrops alternatus was found mostly $(80 \%)$ in grassland, and to a lesser extent in other habitats. Previous data from the Sierras de Ventania described this species in scrublands, shrubby grasslands, streams and rocky areas (Koslowsky 1985, Cei 1986, 1993). Nearby the Sierras de Tandilia, the species was recorded on rock outcrops and in shrubby grasslands (Vega \& Bellagamba 1990). Our results corroborate and extend previous observations on microhabitat use of this species. Although the bulk of specimens were found in grasslands, the species would prefer this environment with moderate selectivity (i.e., low habitat selection and relatively high values of microhabitat diversity and spatial niche breadth).

Finally, the ecological literature recognizes that communities are commonly structured by the interaction of several factors as a response to predators (Toft 1985) or by historical limitations and constraints (Brooks \& McLennan 1991, Cadle \& Greene 1993), among other factors. The present work analyzed the main dimensions of the ecological niche (diet and habitat) suggested by Pianka $(1973,1974)$ in a snake assemblage from the Sierras de Ventania low mountain chain in Argentina. Consistent with previous reports (Arnold 1972, Schoener 1977, Toft 1985, Luiselli 2006, Goodyear \& Pianka 2008), diet instead of habitat was the niche dimension that better explained the ecological partitioning of this snake assemblage. Indeed, paired species comparisons showed a statistically significant low diet overlap for most interactions and a significantly high microhabitat use overlap only in two species pairs. Thus, the asymmetrical overlap values (MacArthur \& Levins 1967) of two species pairs indicated that, under a scenario of resource scarcity and potential competition (Sale 1974, Connell 1980), E. poecilogyrus and P. patagoniensis were likely to be affected by $L$. elegantissimus and B. alternatus, respectively. Our results showed a trend toward a balance between relatively high microhabitat overlapping and low diet overlapping. Furthermore, they fit well with the complementary niches hypothesis proposed by Schoener (1974), which states that coexistence may occur when a high overlap in a particular niche dimension is necessarily balanced out by a low overlap in another dimension, allowing sympatric coexistence and avoiding competitive exclusion.

\section{Acknowledgments}

We thank the Organismo Provincial para el Desarrollo Sostenible de la Provincia de Buenos Aires for the collecting permits. We thank Marcela Quetglas, Diego Barrasso, Santiago Nenda, Sebastián Lyons, Sergio Rosset, and Sebastián Gomez for their help during fieldwork. We thank Germán Moreira, Leopoldo Alvarez, and Mariano Lucia for their assistance in determining some prey items consumed by snakes. We greatly acknowledge two anonymous reviewers whose comments improved our work. We thank curators Julian Faivovich (MACN, Buenos Aires) and Sonia Kretzschmar (FML, Tucumán) for loaning specimens in their care. This study was supported by the Consejo Nacional de Investigaciones Científicas y Técnicas (CONICET) Argentina, Secretaría de Ciencia y Técnica, Universidad Nacional de La Plata (SECYT-UNLP, Project 11/N823), and Secretaría de Ciencia y Tecnología, 
Universidad Nacional de Córdoba (SECYT-UNC, Project 05/1460).

\section{REFERENCES}

ALBARELLI LPP \& SANTOS COSTA MC. 2010. Feeding ecology of Liophis reginae semilineatus (Serpentes: Colubridae: Xenodontinae) in eastern Amazon, Brazil. Zoologia (Curitiba) 27: 87-91.

ANDRADE DV \& ABE AS. 1999. Relationship of venom ontogeny and diet in Bothrops. Herpetologica 55: 200-204.

ARNOLD SJ. 1972. Species densities of predators and their prey. Am Nat 106: 220-236.

BASSO NG. 1990. Estrategias adaptativas en una comunidad subtropical de anuros. Cuad Herpetol, Ser Monogr 1: 1-70.

BEAUPRE SJ \& MONTGOMERY CE. 2007. The meaning and consequences of foraging mode in snakes. In: Reilly SM et al. (Eds), Lizard Ecology: The Evolutionary Consequences of Foraging Mode, Cambridge: Cambridge University Press, p. 334-367.

BELLINI GP, GIRAUDO AR, ARZAMENDIA V \& ETCHEPARE EG. 2015. Temperate snake community in South America: Is diet determined by phylogeny or ecology? PLOS ONE 10(5): e0123237.

BIAVATI G, WIEDERHECKER H \& COLLI GR. 2004. Diet of Epipedobates flavopictus (Anura: Dendrobatidae) in a Neotropical Savanna. J Herpetol 38(4): 510-518.

BILENCA D \& MIÑARRO F. 2004. Identificación de Áreas Valiosas de Pastizal (AVPs) en las Pampas y Campos de Argentina, Uruguay y sur de Brasil. Buenos Aires: Fundación Vida Silvestre Argentina, 323 p.

BRILLOUIN L. 1962. Science and information theory, 2nd ed., New York: Academic Press, 351 p.

BROOKS DR \& MCLENNAN DA. 1991. Phylogeny, Ecology, and Behavior: A Research Program in Comparative Biology. Chicago: University of Chicago Press, 441 p.

BURBRINK FT \& MYERS EA. 2015. Both traits and phylogenetic history influence community structure in snakes over steep environmental gradients. Ecography 38: 1036-1048.

BURGOS JJ. 1968. El clima de la provincia de Buenos Aires en relación con la vegetación natural y el suelo. In: Cabrera AL (Ed), Flora de la provincia de Buenos Aires, Buenos Aires: Colección Científica INTA 4: 33-99.
CABRERA AL. 1976. Regiones fitogeográficas argentinas. In: Kugler WF (Ed), Enciclopedia argentina de agricultura y jardinería, $2^{\text {nd }}$ ed., Buenos Aires: Acme 2: 1-85.

CADLE JE \& GREENE HW. 1993. Phylogenetic patterns, biogeography, and the ecological structure of Neotropical snake assemblages. In: Ricklefs RE \& Schluter D (Eds), Species diversity in ecological communities: historical and geographical perspectives, Chicago: University of Chicago Press, p. 281-293.

CARREIRA S. 2002. Alimentación de los ofidios de Uruguay. Monografías de Herpetología, Barcelona: Asociación Herpetológica Española, Monografías de Herpetología 6: 127

CEI JM. 1986. Reptiles del centro, centro-oeste y sur de la Argentina: Herpetofauna de las zonas áridas y semiáridas. Monografie IV. Torino: Museo Regionale di Scienze Naturali, Monografie 4: 527.

CEI JM. 1993. Reptiles del noroeste, nordeste y este de la Argentina: Herpetofauna de las selvas subtropicales, Puna y Pampas. Monografie XIV. Torino: Museo Regionale di Scienze Naturali, 949 p.

CLARK RW. 2004. Timber rattlesnakes (Crotalus horridus) use chemical cues to select ambush sites. J Chem Ecol 30(3): 607-617.

COLSTON TJ, COSTA GC \& VITT LJ. 2010. Snake diets and the deep history hypothesis. Biol J Linn Soc 101(2): 476-486.

CONNELL JH. 1980. Diversity and the coevolution of competitors, or the ghost of competition past. Oikos 35(2): 131-138.

COOPER WE. 1995. Foraging mode, prey chemical discrimination, and phylogeny in lizards. Anim Behav 50(4): 973-985.

COUTURIER GA \& GRISOLIA C. 1989. Presencia de Philodryas aestivus (Duméril, Bibron y Duméril, 1854) en Sierra de la Ventana (Provincia de Buenos Aires). Bol Asoc Herpetol Arg 5(1-2): 13-13.

CRANWELL JA. 1942. Consideraciones sobre Rhadinaea elegantissima Koslowsky. Rev Argent Zoogeogr 2(3): 143-146.

CRISCI JV, FREIRE S, SANCHO G \& KATINAS L. 2001. Historical biogeography of the Asteraceae from Tandilia and Ventania mountain ranges (Buenos Aires, Argentina). Caldasia 23: 21-41.

DALY JW, GARRAFFO HM, SPANDE TF, YEH HJC, PELTZER PM, CACIVIO P, BALDO D \& FAIVOVICH J. 2008. Indolizidine 2390 and Quinolizidine 275l. Major alkaloids in two Argentinian bufonid toads (Melanophryniscus). Toxicon 52(8): 858-870. 
DE LA SOTA ER. 1967. Composición, origen y vinculaciones de la flora pteridológica de las Sierras de Buenos Aires (Argentina). Bol Soc Argent Bot 11(2-3): 105-128.

DI PIETRO DO, ALCALDE L, WILLIAMS JD \& CABRERA MR. 2012. Geographic distribution. Testudines: Hydromedusa tectifera (South American snake-necked turtle). Herpetol Rev 43(2): 303-303.

DI PIETRO DO, CABRERA MR, WILLIAMS JD, KACOLIRIS FP, CAJADE R \& ALCALDE L. 2018. Distributional patterns and conservation planning for a snake assemblage from temperate South America. J Nat Conserv 45: 79-89.

DIXON JR \& MARKEZICH AL. 1992. Taxonomy and geographic variation of Liophis poecilogyrus (Wied) from South America (Serpentes: Colubridae). Tex J Sci 44: 131-166.

DORCAS ME \& WILLSON JD. 2009. Innovative methods for studies of snake ecology and conservation. In: Mullin SJ \& Seigel RA (Eds), Snakes: Ecology and Conservation, Ithaca: Cornell University Press, p. 5-37.

DURSO AM, WILLSON JD \& WINNE CT. 2013. Habitat influences diet overlap in aquatic snake assemblages. J Zool 291(3): 185-193.

ECKHARDT RC. 1979. The adaptive syndromes of two guilds of insectivorous birds in the Colorado Rocky Mountains. Ecol Monogr 49(2): 129-149.

ESKEW EA, WILLSON JD \& WINNE CT. 2009. Ambush site selection and ontogenetic shifts in foraging strategy in a semi-aquatic pit viper, the Eastern Cottonmouth. J Zool 277(2): 179-186.

FAUTH JE, BERNARDO J, CAMARA M, RESETARITS JR WJ, VAN BUSKIRK J \& MCCOLLUM SA. 1996. Simplifying the jargon of community ecology: a conceptual approach. Am Nat 147(2): 282-286.

FORSMAN A \& SHINE R. 1997. Rejection of non-adaptive hypotheses for intraspecific variation in trophic morphology in gape-limited predators. Biol J Linn Soc 62(2): 209-223.

FOSTER MS. 2012. Standard techniques for inventory and monitoring. In: McDiarmid RW et al. (Eds), Reptile biodiversity: Standard methods for inventory and monitoring, Berkeley: University of California Press, $p$. 205-271.

FRANGI JL \& BARRERA MD. 1996. Biodiversidad y dinámica de pastizales en la Sierra de la Ventana, Provincia de Buenos Aires, Argentina. In: Sarmiento G \& Cabido M (Eds), Biodiversidad y Funcionamiento de Pastizales y Sabanas en América Latina, Mérida: CYTED-CIELAT, p. 133-162.
FRANGI JL \& BOTTINO OJ. 1995. Comunidades vegetales de la Sierra de la Ventana, Provincia de Buenos Aires, Argentina. Rev Fac Agron (La Plata) 71(1): 93-133.

GALLARDO JM. 1968. Dos nuevas especies de Iguanidae (Sauria) de la Argentina. Neotropica 14: 1-8.

GALLARDO JM. 1970. Estudio ecológico sobre los anfibios y reptiles del sudoeste de la provincia de Buenos Aires, Argentina. Rev Mus Argent Cienc Nat 10: 27-63.

GALLARDO JM. 1977. Reptiles de los alrededores de Buenos Aires. Buenos Aires: EUDEBA, 213 p.

GERRITSEN J \& STRICKLER JR. 1977. Encounter probabilities and community structure in zooplankton: a mathematical model. J Fish Res Board Can 34(1): 73-82.

GIRAUDO AR, ARZAMENDIA V, LOPEZ SM, QUAINI RO, PRIETO YA, LEIVA LA, REGNER SA \& URBAN JM. 2008. Serpientes venenosas de Santa Fe, Argentina: conocimientos sobre su historia natural aplicados para la prevención de ofidismo. FABICIB 12: 69-89.

GONZAGA LAP, CASTIGLIONI GDA \& ALVES MA. 1997. Philodryas patagoniensis (NCN). Diet Herpetol Rev 28(3): 154-154

GOODYEAR SE \& PIANKA ER. 2008. Sympatric ecology of five species of fossorial snakes (Elapidae) in Western Australia. J Herpetol 42(2): 279-285.

GOTELLI NJ \& ENTSMINGER GL. 2004. EcoSim: Null models software for ecology. Version 7.71. Jericho: Acquired Intelligence Inc \& Kesey-Bear. Available at: http:// garyentsminger.com/ecosim/index.htm Accessed on 1 July 2018.

GREENE HW. 1983. Dietary correlates of the origin and radiation of snakes. Am Zool 23(2): 431-441.

GREENE HW. 1992. The ecological and behavioral context of pitviper evolution. In: Campbell JA \& Brodie Jr ED (Eds), Biology of the Pitvipers, Tyler: Selva Press, p. 107-117.

GREENE HW. 1997. Snakes: The evolution of mystery in nature. Berkeley: University of California Press, 366 p.

HAMMER Ф, HARPER DAT \& RYAN PD. 2001. PAST: Paleontological Statistics Software Package for Education and Data Analysis. Version 3.14. Palaeontol Electron 4(1): 1-9. Available at: http://folk.uio.no/ohammer/past. Accessed on 1 July 2018.

HAMPTON PM \& FORD NB. 2007. Effects of flood suppression on natricine snake diet and prey overlap. Can J Zool 85(7): 809-814.

HARTMANN PA \& MARQUES OAV. 2005. Diet and habitat use of two sympatric species of Philodryas (Colubridae), in south Brazil. Amphibia-Reptilia 26(1): 25-31. 
HENDERSON RW. 1974. Resource partitioning among the snakes of the University of Kansas Natural History Reservation: a preliminary analysis. Milw Public Mus Contrib Biol Geol 1: 1-11.

HENDERSON RW \& BINDER MH. 1980. The ecology and behavior of the vine snakes (Ahaetulla, Oxybelis, Thelotornis, Uromacer): a review. Milw Public Mus Contrib Biol Geol 37: 1-38.

HEYER WR. 1988. On frog distribution patterns east of the Andes. In: Vanzolini PE \& Heyer WR (Eds), Proceedings of the Workshop on Neotropical Distribution Patterns. Academia Brasileira de Ciências, Rio de Janeiro, p. 245-274.

HUEY RB \& PIANKA ER. 1981. Ecological consequences of foraging mode. Ecology 62(4): 991-999.

HURTUBIA J. 1973. Trophic diversity measurement in sympatric predatory species. Ecology 54(4): 885-890.

HUTCHINSON GE. 1957. Concluding remarks. Cold Spring Harb Symp Quant Biol 22: 415-427.

JAKSIC FM, GREENE HW \& YÁÑEZ JL. 1981. The guild structure of a community of predatory vertebrates in central Chile. Oecologia 49(1): 21-28.

JOCQUÉ R \& ALDERWEIRELDT M. 2005. Lycosidae: the grassland spiders. Acta Zool Bulg 1: 125-130.

KLEY NJ. 2001. Prey transport mechanisms in blindsnakes and the evolution of unilateral feeding systems in snakes. Am Zool 41(6): 1321-1337.

KOSLOWSKY J. 1895. Reptiles y batracios de la Sierra de la Ventana (Provincia de Buenos Aires). Rev Mus La Plata 7(1896): 151-156.

KREBS JR. 1978. Optimal foraging: decision rules for predators. In: Krebs JR \& Davies NB (Eds), Behavioural Ecology: An Evolutionary Approach, Sunderland: Sinauer Associates, Inc, p. 23-63.

KRISTENSEN MJ \& FRANGI JL. 1995. Mesoclimas de pastizales de la Sierra de la Ventana. Ecol Austral 5(1): 55-64.

LEMA T DE. 1973. As serpentes do estado do Rio Grande do Sul. Iheringia. Sér Div 3: 19-33.

LEMA T DE, LEITÃO DE ARAúJO M \& AZEVEDO ACP. 1983. Contribuição ao conhecimento da alimentação e do modo alimentar de serpentes do Brasil. Comun Mus Ciênc Tecnol PUCRS Sér Zool 26: 41-121.

LEVINS R. 1968. Evolution in Changing Environments: Some Theoretical Explorations. Monographs in Population Biology, Princeton: Princeton University Press 2: 132.
LÓPEZ MS. 2003. Philodryas patagoniensis (NCN). Diet Herpetol Rev 34: 71-72.

LÓPEZ MS \& GIRAUDO AR. 2008. Ecology of the Snake Philodryas patagoniensis (Serpentes, Colubridae) from Northeast Argentina. J Herpetol 42: 474-480.

LUISELLI L. 2006. Resource partitioning and interspecific competition in snakes: the search for general geographical and guild patterns. Oikos 114(2): 193-211.

MACARTHUR R \& LEVINS R. 1967. The limiting similarity, convergence and divergence of coexisting species. Am Nat 101(921): 377-385.

MARQUES OAV, SAWAYA RJ, STENDER OLIVEIRA F \& FRANCA FGR. 2006. Ecology of the colubrid snake Pseudablabes agassizii in South-Eastern South America. Herpetol J 16(1): 37-45.

MARTINS M, MARQUES OAV \& SAZIMA I. 2002. Ecological and phylogenetic correlates of feeding habits in neotropical pitvipers of the genus Bothrops. In: Schuett GW et al. (Eds), Biology of the vipers, Eagle Mountain: Eagle Mountain Publishing, p. 307-328.

MARTINS M \& OLIVEIRA ME. 1998. Natural history of snakes in forests of the Manaus region, central Amazonia, Brazil. Herpetol Nat Hist 6(2): 78-150.

MEBS D. 2002. Venomous and Poisonous Animals. Boca Raton: CRC Press, 340 p.

MICHAUD EJ \& DIXON JR. 1989. Prey items of 20 species of the neotropical colubrid snake genus Liophis. Herpetol Rev 20(2): 39-41.

MIRANDA M, COUTURIER G \& WILLIAMS JD. 1983. Guía de los Ofidios Bonaerenses, $2^{\text {nd }}$ ed., La Plata: Asoc Coop Jardín Zoológico de La Plata, 72 p.

MOHAMMADI S, GOMPERT Z, GONZALEZ J, TAKEUCHI H, MORI A \& SAVITZKY AH. 2016. Toxin-resistant isoforms of $\mathrm{Na}^{+} /$ $\mathrm{K}^{+}$-ATPase in snakes do not closely track dietary specialization on toads. Proc R Soc B 283: 2016211.

MULLIN SJ \& COOPER RJ. 1998. The foraging ecology of the snake Elaphe obsoleta spiloides - visual stimuli facilitate location of arboreal prey. Amer Midl Nat 140: 397-401.

OLIVEIRA RB, DI BERNARDO M, PONTES GMF, MACIEL AP \& KRAUSE L. 2001. Dieta e comportamento alimentar da cobranariguda, Lystrophis dorbignyi (Duméril \& Duméril, 1854), no Litoral Norte do Rio Grande do Sul, Brasil. Cuad Herpetol 14(2): 117-122.

OREJAS MIRANDA BR. 1966. The snake genus Lystrophis in Uruguay. Copeia 1966(2): 193-205. 
PANZERA A \& MANEYRO R. 2014. Feeding Biology of Lygophis anomalus (Dipsadidae, Xenodontinae). South Am J Herpetol 9(2): 75-82.

PARDIÑAS UFJ, ABBA AM \& MERINO ML. 2004. Micromamíferos (Didelphimorphia y Rodentia) del sudoeste de la provincia de Buenos Aires (Argentina): Taxonomía y distribución. Mastozool Neotrop 11(2): 211-232.

PÉREZ CA \& FRANGI JL. 2000. Grassland biomass dynamics along an altitudinal gradient in the Pampa. J Range Manag 53(5): 518-528.

PERRY G \& PIANKA ER. 1997. Animal foraging: past, present and future. Trends Ecol Evol 12(9): 360-364.

PIANKA ER. 1973. The structure of lizard communities. Annu Rev Ecol Systemat 4: 53-74.

PIANKA ER. 1974. Niche overlap and diffuse competition. Proc Nat Acad Sci 71(5): 2141-2145.

PIANKA ER. 1975. Niche relations of desert lizards. In: Cody ML \& Diamong JM (Eds), Ecology and evolution of communities, Cambridge: Harvard University Press, p. 292-314.

PIANKA ER. 1982. Ecología evolutiva. Barcelona: Omega, $536 \mathrm{p}$.

PIELOU EC. 1969. An introduction to mathematical ecology. New York: Wiley- Interscience, 286 p.

PINTO RR \& FERNANDES R. 2004. Reproductive biology and diet of Liophis poecilogyrus poecilogyrus (Serpentes, Colubridae) from southeastern Brazil. Phyllomedusa 3: 9-14.

PLUMMER MV. 1981. Habitat utilization, diet, and movements of a temperate arboreal snake (Opheodrys aestivus). J Herpetol 15(4): 425-432.

POUGH FH \& ANDREWS RM. 1985. Energy costs of subduing and swallowing prey for a lizard. Ecology 66(5): 1525-1533.

PRIETO YA, GIRAUDO AR \& LÓPEZ MS. 2012. Diet and Sexual Dimorphism of Liophis poecilogyrus (Serpentes, Dipsadidae) from the Wetland Regions of Northeast Argentina. J Herpetol 46(3): 402-406.

PUNZO F. 1974. Comparative analysis of the feeding habits of two species of Arizona blind snakes, Leptotyphlops $h$. humilis and Leptotyphlops d. dulcis. J Herpetol 8: 153-156.

REINERT HK. 1993. Habitat selection in snakes. In: Seigel RA \& Collins JT (Eds), Snakes: Ecology and Behavior, New York: MacGraw-Hill, p. 201-240.

SALE PF. 1974. Overlap in resource use, and interspecific competition. Oecologia 17(3): 245-256.
SAVITZKY AH, MORI A, HUTCHINSON DA, SAPORITO RA, BURGHARDT GM, LILLYWHITE HB \& MEINWALD J. 2012. Sequestered defensive toxins in tetrapod vertebrates: principles, patterns, and prospects for future studies. Chemoecology 22(3): 141-158.

SAZIMA I. 1992. Natural history of the jararaca pitviper, Bothrops jararaca, in southeastern Brazil. In: Campbell JA \& Brodie JR ED (Eds), Biology of the Pitvipers, Tyler: Selva press, p. 199-216.

SCHOENER TW. 1974. Resource partitioning in ecological communities. Science 185(4145): 27-39.

SCHOENER TW. 1977. Competition and the niche. In: Tinkle DW \& Gans C (Eds), Biology of the Reptilia,New York: Academic Press 7: 35-136.

SCHWENK K. 1995. Of tongues and noses: Chemoreception in lizards and snakes. Trends Ecol Evol 10(1): 7-12.

SELLÉS MARTínEZ J. 2001. Geología de la Ventania (Provincia de Buenos Aires, Argentina). J Iber Geol 27: 43-69.

SERIÉ P. 1919. Notas sobre la alimentación de algunos ofidios. Rev Jard Zool Buenos Aires 60: 307-328.

SHANNON CE \& WEAVER W. 1949. The mathematical theory of communications. Urbana: University of Illinois Press, 117 p.

SHINE R. 1987. Ecological ramifications of prey size: food habits and reproductive biology of Australian copperhead snakes (Austrelaps, Elapidae). J Herpetol 21(1): 21-28.

SHINE R \& WEBB JK. 1990. Natural history of Australian typhlopid snakes. J Herpetol 24(4): 357-363.

THORPE RS, BROWN RP, DAY M, MALHOTRA A, MCGREGOR DP \& WUSTER W. 1994. Testing ecological and phylogenetic hypothesis in microevolutionary studies. In: Eggleton P \& Vane Wright R (Eds), Phylogenetics and Ecology, New York: Academy Press, 17: 189-206.

TOFT CA. 1980. Feeding ecology of thirteen syntopic species of anurans in a seasonal tropical environment. Oecologia 45(1): 131-141.

TOFT CA. 1981. Feeding ecology of Panamanian litter anurans: patterns in diet and foraging mode. J Herpetol 15(2): 139-144.

TOFT CA. 1985. Resource partitioning in amphibians and reptiles. Copeia 1985(1): 1-21.

VAIRA M ET AL. 2012. Categorización del estado de conservación de los anfibios de la República Argentina. Cuad Herpetol 26(Suppl 1): 131-159.

VARGAS GIL JR \& SCOPPA CO. 1973. Suelos de la Provincia de Buenos Aires. Rev Inv Agrop, INTA 10(3): 57-79. 
VAZ FERREIRA R, COVELLO DE ZOLESSI L \& ACHAVAL F. 1970. Ovoposición y desarrollo de ofidios y lacertilios en hormigueros de Acromyrmex. Physis 29: 431-459.

VEGA L \& BELLAGAMBA P. 1990. Lista comentada de la Herpetofauna de las Sierras de Balcarce y Mar del Plata, Buenos Aires, Argentina. Cuad Herpetol 5: 10-14.

VIÑAS M. 1985. Notas sobre la biología de Pseudablabes agassizii Jan. Bol Asoc Herpetol Argent 1: 16-16.

VIÑAS M, DANERI G \& GNIDA G. 1989. Presencia de Pseudablabes agassizii (Jan, 1863) en Sierra de la Ventana (provincia de Buenos Aires), y confirmación para la provincia de la Pampa. Bol Asoc Herpetol Arg 5: 13-14.

VITT LJ. 1983. Ecology of an anuran-eating guild of terrestrial tropical snakes. Herpetologica 39(1): 52-66.

VITT LJ \& PIANKA ER. 2005. Deep history impacts presentday ecology and biodiversity. Proc Nat Acad Sci 102(22): 7877-7881.

VITT LJ \& VANGILDER LD. 1983. Ecology of a snake community in northeastern Brazil. Amphibia-Reptilia 4: 273-296.

VITT LJ \& ZANI PA. 1996. Organization of a taxonomically diverse lizard assemblage in Amazonian Ecuador. Can J Zool 74: 1313-1335.

WEBB JK \& SHINE R. 1993. Prey-size selection, gape limitation and predator vulnerability in Australian blindsnakes (Typhlopidae). Anim Behav 45(6): 1117-1126.

WEBB JK, SHINE R, BRANCH WR \& HARLOW PS. 2000. Lifehistory strategies in basal snakes: reproduction and dietary habits of the African thread snake Leptotyphlops scutifrons (Serpentes: Leptotyphlopidae). J Zool 250(3): 321-327.

WHITE M \& KOLB JA. 1974. A preliminary study of Thamnophis near Sagehen Creek, California. Copeia 1974(1): 126-136.

WILLIAMS JD \& SCROCCHI GJ. 1994. Ofidios de agua dulce de la República Argentina. In: De Castellanos ZA (Ed), Fauna de Agua Dulce de la República Argentina, La Plata: CICPBA, p. 1-55.

WINEMILLER KO \& PIANKA ER. 1990. Organization in natural assemblages of desert lizards and tropical fishes. Ecol Monogr 60(1): 27-55.

WINKLER FJM, WALTENBERG LM, SANTOS PA, NASCIMENTO DS, VRCIBRADIC D \& SLUYS MV. 2011. New records of anuran prey for Thamnodynastes strigatus (Günther, 1858) (Serpentes: Colubridae) in a high-elevation area of southeast Brazil. Herpetol Notes 4(1): 123-124.
WÜSTER W, DUARTE MR \& SALOMÃO MG. 2005. Morphological correlates of incipient arboreality and ornithophagy in island pitvipers, and the phylogenetic position of Bothrops insularis. J Zool Lond 266(1): 1-10.

YANOSKY AA. 1989. La ofidiofauna de la reserva ecológica El Bagual, Formosa: Abundancia, utilización de los hábitats y estado de situación. Cuad Herpetol 4(3): 11-14.

ZAHER H, GRAZZIOTIN FG, CADLE JE, MURPHY RW, MOURA LEITE JC \& BONATTO SL. 2009. Molecular phylogeny of advanced snakes (Serpentes, Caenophidia) with an emphasis on South American Xenodontines: a revised classification and descriptions of new taxa. Pap Avulsos de Zool (São Paulo) 49(11): 115-153.

ZHENG Y \& WIENS JJ. 2016. Combining phylogenomic and supermatrix approaches, and a time-calibrated phylogeny for squamate reptiles (lizards and snakes) based on 52 genes and 4162 species. Mol Phylogenet Evol 94(Pt B): 537- 547.

\section{SUPPLEMANTARY MATERIAL}

\section{Appendix S1. \\ Table SI.}

\section{How to cite}

DI PIETRO DO, WILLIAMS JD, CABRERA MR, ALCALDE L, CAJADE R \& KACOLIRIS FP. 2020. Resource partitioning in a snake assemblage from east-central Argentina. An Acad Bras Cienc 92: e20180766. DOI. 10.1590/0001-3765202020180766

Manuscript received on July 26, 2018; accepted for publication on November 5, 2018

\section{DIEGO O. DI PIETRO 1}

http://orcid.org/0000-0001-7329-6429

\section{JORGE D. WILLIAMS}

http://orcid.org/0000-0002-2644-4350

\section{MARIO R. CABRERA ${ }^{2}$}

http://orcid.org/0000-0001-7116-5169

\section{LEANDRO ALCALDE ${ }^{3}$}

http://orcid.org/0000-0002-4365-2434

\section{RODRIGO CAJADE}

http://orcid.org/0000-0003-3614-2054

\section{FEDERICO P. KACOLIRIS ${ }^{1}$}

http://orcid.org/0000-0001-6057-1591 
'Sección Herpetología, División Zoología Vertebrados, Facultad de Ciencias Naturales y Museo, Universidad Nacional de La Plata, Av. 122 y 60, 1900 La Plata, Argentina

${ }^{2}$ Universidad Nacional de Córdoba, Facultad de Ciencias Exactas, Físicas y Naturales, Museo de Zoología, and Instituto de Diversidad y Ecología Animal (IDEA) CONICET/ UNC, Vélez Sarsfield 299, 5000 Córdoba, Argentina ${ }^{3}$ Sección Herpetología, Instituto de Limnología Dr. R.A. Ringuelet (contribution number 1149) CONICET, Blvd. 120 y 62, 1900 La Plata, Argentina

${ }^{4}$ Laboratorio de Herpetología, Departamento de Biología, Facultad de Ciencias Exactas Naturales y Agrimensura, Universidad Nacional del Nordeste, Av. Libertad 5470, 3400 Corrientes, Argentina

Correspondence to: Diego Omar Di Pietro

E-mail:dipietro@fcnym.unlp.edu.ar

\section{Author contributions}

DOD obtained the data, analyzed and interpreted the results. JDW and MRC directed the research and provided financial support. LA, RC and FPK contributed to statistical analysis. DOD wrote the manuscript with the contribution of all co-authors

\section{(cc) BY}

